\title{
FROM DEBATE TO DIALOGUE: AUTHENTIC INTERFAITH FRIENDSHIP FROM THE PERSPECTIVE OF CHRISTIAN THEOLOGY
}

YOHANES KRISMANTYOSUSANTA*, AND FEBRIANI UPA**

\author{
'Dosen Institut Agama Kristen Negeri Toraja, Jl. Poros Makale-Makassar Km. 11,5 Mengkendek, Tana Toraja, Sulawesi \\ Selatan, "'Mahasiswa Pascasarjana Institut Agama Kristen Negeri Toraja, JI. Poros Makale-Makassar Km. 11,5 Mengkendek, Tana \\ Toraja, Sulawesi Selatan. Email: yohanessusanta@gmail.com
}

\begin{abstract}
This study is qualitative which employs literature reviews of materials discussing multifaith dialogues from the Christian perspectives. It believes that multifaith debate is already out-of-date and rather counterproductive. This study is to demonstrate the importance of dialogues among different faiths to foster interfaith brotherhood. It found that Christian theological attitudes towards other religions can be categorized into three major types known as tripolar typologies: exclusivism, inclusivism, and pluralism which was developed by Alan Race. This paper proposes an interfaith friendship dialogue based on mutual understanding as the essence of Christian existence. Truly authentic dialogue is only possible if it is established in friendly relationships between faiths.
\end{abstract}

KEY WORDS: interfaith dialogue, others, theology of friendship, tripolar typology

\section{DARI DEBAT KE DIALOG: PERSAHABATAN ANTARIMAN YANG AUTENTIK DARI PERSPEKTIF TEOLOGI KRISTEN}

\begin{abstract}
Abstrak
Metode penelitian dalam tulisan ini ialah kualitatif. Secara khusus, penelitian ini menggunakan studi pustaka dengan memanfaatkan sejumlah literatur yang mengulas tentang dialog antariman dan teori persahabatan dari perspektif Kristen. Perdebatan antaragama adalah sesuatu yang usang karena hanya akan semakin menumbuhkan benih-benih kebencian dan bersifat kontraproduktif. Signifikansi dari penelitian ini ialah guna memperlihatkan pentingnya dialog untuk menjembatani perbedaan dan memupuk persaudaraan antariman. Penelitian ini memperlihatkan bahwa sikap teologis Kristen terhadap agama lain dikelompokkan ke dalam tiga bagian besar yang dikenal dengan tipologi tripolar, yaitu eksklusivisme, inklusivisme, dan pluralisme. Teori tipologi tripolar ini dikembangkan oleh Alan Race. Tulisan ini juga menunjukkan bahwa diperlukan pendekatan dialog yang melampaui tipologi tripolar tersebut. Tulisan ini mengusulkan dialog persahabatan antariman dengan dasar pemahaman bahwa dialog antariman merupakan hakikat keberadaan Kristen. Dialog yang benar-benar autentik hanya mungkin terjadi jika terbangun dalam relasi persahabatan antariman.
\end{abstract}

KATA KUNCI: dialog antariman, sang liyan, tipologi tripolar, teologi persahabatan

* Naskah diterima Februari 2021, direvisi April 2021, dan disetujui untuk diterbitkan Mei 2021

Dialog, 44(1), 2021, 1-11

https://jurnaldialog.kemenag.go.id,p-ISSN:0126-396X,e-ISSN:2715-6230

This is open access article under CC BY-NC-SA-License

(https://creativecommons.org/license/by-nc-sa/4.0/)

Dialog Vol. 44, No.1, Juni 2021 


\section{A. Pendahuluan}

Perdebatan antarpribadi maupun antarkelompok kerapkali dijumpai di tengah masyarakat, tak terkecuali perdebatan antaragama. Debat yang mengatasnamakan dua atau lebih pihak dari agama yang berbeda saat ini juga dengan mudah dijumpai baik yang berlangsung secara luring ataupun daring. Secara khusus saat ini perdebatan tersebut banyak berlangsung di media sosial seperti YouTube. Dengan mudah hal tersebut dijumpai dalam berbagai kanal YouTube di tanah air. Sayangnya, perdebatan antaragama yang terjadi kerapkali dilandasi dengan keinginan masing-masing pihak untuk mencari kesalahan dan menjatuhkan pihak lain serta menganggap ajaran agama yang paling benar. Akibatnya, perdebatan yang berlangsung bukan hanya semakin memperlebar jurang perbedaan tetapi sekaligus, entah disadari atau tidak, justru menyemai dan menumbuhsuburkan benih kebencian di masing-masing pihak. Dalam konteks Indonesia, kebencian tersebut lalu berkembang menjadi konflik yang melibatkan pemeluk agama yang berbeda.

Menurut penulis, debat antaragama adalah hal yang tidak perlu dan sia-sia sebab perdebatan dari dua ajaran yang berbeda tak akan ada ujung pangkalnya. Perdebatan tersebut mestinya diakhiri dan diganti dengan dialog. Bahkan, dialog yang sudah jamak dilakukan pun masih saja kerapkali menemui jalan buntu, apalagi debat antaragama. Sebagaimana dikatakan oleh Irfanullah dan Hasse bahwa debat yang menonjolkan klaim kebenaran yang absolut akan semakin memperumit dialog yang ujungujungnya akan berakhir dengan debat kusir atau pertarungan argumentasi yang tidak berfaedah dan tidak produktif (Irfanullah \& Hasse, 2016).

Faktanya, dialog yang selama ini telah dilakukan kerapkali jatuh ke ajang debat yang menyinggung perasaan. Misalnya seringkali ayat dari Kitab Suci agama lain justru dijadikan senjata untuk memojokkan agama lain tersebut. Padahal Menurut Franz Magnis-Suseno, hal itu adalah suatu kebiasaan yang sering juga menjadi tanda kebodohan mereka yang memakai ayat-ayat itu. Jadi, kalau ada ayat-ayat yang mengganggu kita, kita harus pertama kali bertanya pada agama yang berpegang pada buku itu sebagai Kitab Suci, apa yang mereka katakan (Magnis-Suseno, 2014).

Terkait dengan dialog itu sendiri, menurut J.
B. Banawiratma dan Zainal Abidin Bagir, dalam konteks dialog itu sendiri, Indonesia mengalami sejarah panjang terkait praktik dialog antarumat beragama. Hal tersebut tampak melalui forumforum dialog antarumat beragama atau diskusi mengenai dialog baik pada tingkat regional maupun internasional (Banawiratma \& Bagir, 2010).

Dialog sebagai aktivitas yang terlembagakan di Indonesia telah dimulai sejak 1960-an, dipromosikan dengan gencar oleh pemerintah; dilakukan pada tingkat masyarakat; dan juga dikembangkan dalam dunia akademis. Sementara dialog telah sering dilakukan dan banyak gagasan mengenai dialog dikembangkan, namun kajian mengenai praktik dialog tersebut belum jamak (Banawiratma \& Bagir, 2010).

Menurut Schumann sebagaimana dikutip Irfanullah dan Hasse, dialog adalah sebuah keniscayaan sebab tidak ada agama atau komunitas keagamaan yang tak pernah mengalami perjumpaan dengan agama lainnya (Irfanullah \& Hasse, 2016).

Mengutip Banawiratma dan Bagir, istilah dialog antariman kemudian banyak dipakai tatkala istilah agama tidak lagi bermakna netral. Istilah agama pada awal tahun 1970-an saat itu berada di bawah hegemoni pemerintah dan banyak digunakan dengan bobot dan untuk kepentingan politik Orde Baru. Penggunaan kata iman dalam konteks ini mengandung makna dekonstruktif, yaitu hendak membebaskan diri dari hegemoni tersebut (Banawiratma \& Bagir, 2010).

Signifikansi atau pentingnya penelitian ini terkait dengan relasi antarumat beragama yang berbeda, yang kerapkali masih diwarnai oleh rasa saling curiga entah secara kasat mata maupun "diam-diam," yang pada gilirannya berujung pada konflik dan permusuhan (Nazmudin, 2017). Inilah masalah utama yang menjadi urgensi dari dialog antariman dalam konteks Indonesia. Penelitian ini penting guna menawarkan konsep dialog bukan sekadar basa-basi atau semata karena kewajiban tetapi hal ini terkait erat dengan relasi sebagai sesama manusia dan sesama ciptaan Tuhan. Rumusan masalah yang hendak diangkat terkait bagaimana pola relasi antaragama di Indonesia selama ini, serta bagaimana teologi persahabatan dalam perspektif Kristen memberikan sumbangsih bagi terciptanya dialog 
antariman yang autentik.

Penelitian di Indonesia yang membahas tema dialog antaragama sudah jamak dilakukan. Akan tetapi penelitian terbaru dalam kurun waktu sepuluh tahun terakhir (2010-2020), sejauh amatan penulis, yang secara khusus menelaah dialog antaragama dari perspektif Kristen, belum banyak. Dalam amatan terbatas, beberapa karya terbaru yang membahas topik tersebut di antaranya, buku karangan Leonardo Samosir berjudul Agama Dengan Dua Wajah: Refleksi Teologis Atas Tradisi Dalam Konteks. Buku ini memperlihatkan bahwa hubungan antaragama di Indonesia mengalami pasang surut dan secara khusus pola relasi antaragama umumnya terbagi atas tiga sikap yaitu eksklusif, inklusif, dan pluralis. Buku ini juga membahas bagaimana pola relasi yang terjadi antaragama dalam konteks Indonesia yang diwarnai kekerasan dan kedamaian (Samosir, 2010). Selanjutnya buku karangan Herman Panda berjudul Agama-agama dan Dialog Antar-agama dalam Pandangan Kristen. Temuan dalam buku tersebut menunjukkan bahwa terdapat pergeseran sikap pemeluk agama Katolik dalam relasi antaragama di Indonesia. Secara khusus buku ini membahas tentang dasar teologis dialog antaragama dari perspektif iman Kristen Katolik pasca konsili Vatican II (Panda, 2013). Kemudian buku karya Franz MagnisSuseno berjudul Iman Dan Hati Nurani: Gereja Berhadapan Dengan Tantangan-Tantangan Zaman yang membahas sejumlah praktik dialog antaragama yang masih menegasikan yang lain dan dalam perkembangan awalnya hanya terjadi di kalangan elit (Magnis-Suseno, 2014).

Sementara itu dalam sejumlah jurnal ilmiah, penelitian sejenis misalnya dijumpai dalam tulisan Nur Hidayati yang mengulas peran komisi hubungan antarumat beragama Gereja Katolik dalam membangun dialog dengan umat beragama lain (Nur Hidayati, 2019). Selanjutnya artikel jurnal yang ditulis oleh Daniel Ronda membahas tentang peran para pemimpin Kristen dalam dialog dengan penganut agama lain (Ronda, 2019).

Meskipun tulisan ini akan memanfaatkan teori dari beberapa sumber di atas, akan tetapi dalam tulisan ini, penulis hendak mengangkat sisi lain dari dialog antariman. Dialog semestinya tentu tidak dibarengi dengan perdebatan teologis untuk mencari menang-kalah, melainkan dialog autentik yang disertai dengan persahabatan. Harus diakui bahwa masalah agama adalah sesuatu yang sangat sensitif, sebab hal ini terkait keimanan yang akan menimbulkan perbedaan yang tajam secara aksiologis. Hal inilah yang dapat menimbulkan konflik. Akan tetapi, menurut penulis, karena perbedaan adalah sebuah keniscayaan, maka perbedaan adalah sesuatu yang harus diterima sekaligus dirayakan. Oleh karena itulah, persahabatan menjadi suatu konsep yang harus dikedepankan dalam sebuah dialog. Sebab persahabatan adalah langkah awal dalam dialog. Justru dalam persahabatan antarimanlah, dialog kehidupan dapat sungguh-sungguh berlangsung secara autentik.

\section{B. Metode Penelitian}

Penelitian ini menggunakan pendekatan studi pustaka. Dalam penelitian ini akan dikaji sumber pustaka, baik berupa buku-buku maupun artikel jurnal yang membahas teori dialog antariman dan persahabatan, khususnya dari perspektif teologi Kristen. Kemudian, penelitian ini akan melihat sumbangsih teori dialog dan teologi persahabatan antariman tersebut dalam perjumpaan dengan penganut agama lain dalam konteks Indonesia.

\section{Hasil dan Pembahasan Ambivalensi Agama}

Scott Appleby mengatakan bahwa agama sesungguhnya bersifat ambivalen atau memiliki dua wajah yaitu damai dan kekerasan (Appleby, 2000). Di satu sisi, agama dibutuhkan karena dianggap mampu memberikan keseimbangan hidup, orientasi, bahkan identitas. Akan tetapi pada sisi yang lainnya, agama memiliki sisi negatif. Sisi negatif ini dapat disebabkan oleh adanya potensi inheren di dalam diri agama itu sendiri, yang bisa juga disebabkan oleh interpretasi para pemegang tradisi (Samosir, 2010).

Agama secara inheren memiliki potensi untuk menghapus "yang lain." Dasar dari potensi negatif ini adalah klaim sebagai satu-satunya yang benar. Pola pikir "either-or' hanya mengizinkan satu yang benar. Pola pikir tersebut dalam sejarah terbukti telah menjadi salah satu sebab timbulnya gesekan bahkan kekerasan yang mengusung atribut agama. Contoh yang paling jelas adalah perang salib. Di sana kepentingan politik bercampur baur dengan perasaan saleh: tanah suci Palestina harus dibebaskan dari kekuasaan 
bangsa Arab yang muslim. Pola yang sama berjalan terus walaupun dalam cara yang lebih halus. Misi pada abad-abad yang lalu sering diidentikkan dengan menyebarkan agama Kristen di daerah yang bukan Kristen (proselit) (Samosir, 2010).

Dengan potensi negatif ini kedamaian dunia bisa terancam, karena di zaman sekarang, agama (atau lebih tepat: penganut agama) hidup berdampingan satu sama lain. Ketika para penganut agama ikut dalam pola ini, maka bagi mereka agamanya lah yang benar, yang lain salah. Dengan begitu, mereka menolak sesama yang ada di samping mereka yang bisa saja lebih saleh daripada mereka (Samosir, 2010).

Hal senada disampaikan oleh Musdah Mulia yang berpendapat bahwa sekalipun semua agama mengajarkan kedamaian dan penghormatan kepada sesama manusia, namun sebagai sebuah sistem ajaran, agama "masih membuka peluang penafsiran yang mendukung bentuk-bentuk kekerasan" (Mulia, 2013).

Bahaya yang kemudian ditimbulkan terkait relasi dengan orang lain atau penganut agama yang berbeda adalah distorsi dalam penafsiran atas teks-teks Kitab Suci. Sumartana mengatakan, "menyebut orang lain kafir dapat merupakan awal dari praktik kekerasan yang dibenarkan dan memperoleh legitimasi teologis" (Sumartana, 2005).

Penafsiran yang keliru atas beberapa ayat dalam Kitab Suci yang berisi kekerasan, perang, dan balas dendam terhadap musuh menjadi salah satu dasar tindakan yang diambil dan diyakini sebagai hal yang benar. Keyakinan demikian akhirnya melahirkan sikap eksklusif dalam diri penganut agama yang memandang manusia lain sebagai kawan atau lawan, pengikut Tuhan atau kafir (Mulia, 2013).

Pengkonsepan dan kristalisasi dalam bentuk ajaran atau ritus bisa menjadikan agama menjadi represif. Agama sering dianggap mutlak dan dengan begitu 'memutlakkan" Yang Mahatinggi dan Mahabesar. Padahal, agama dalam bentuk konkritnya tidak terlepas dari situasi tempat agama hidup (Samosir, 2010). Selain itu, sebagaimana dikatakan oleh Kenan B. Osborne, jika Allah itu infinitum, maka tidak ada satupun agama dapat mengklaim bahwa hanya dirinya, menyembah satu-satunya Allah yang tak terhingga itu (Osborne, 2015). Pusat orientasi dialog antaragama ialah Allah yang Satu, bukan keberagaman cara manusia mempresentasikan Allah (agama-agama) (Osborne, 2015). Oleh karena itu, Hans Küng tepat ketika mengatakan, tidak ada damai di muka bumi ini kalau agamaagama tidak berdamai (Küng, 2010).

Pemikiran Küng ini mengandaikan semua agama hidup berdampingan tanpa perlu saling membuang dan menindas atau bahkan ia mengandaikan sebuah dialog dalam ketulusan (Samosir, 2010).

\section{Eksklusivisme, Inklusivisme, Pluralisme Sebagai Bentuk Sikap terhadap Agama Lain}

Umumnya ketiga sikap/posisi teologis Kristiani terhadap agama lain (penganut agama lain) digolongkan menjadi tiga macam kelompok, yaitu eksklusivisme, inklusivisme, dan pluralisme.

\section{Eksklusivisme}

Semboyan extra ecclesiam nulla salus (tidak ada keselamatan di luar Gereja) maupun extra ecclesiam nulla propheta (tidak ada nabi di luar Gereja) dikukuhkan dalam konsili Florence tahun 1442 (Qurtuby, 2020). Maksudnya bahwa jaminan keselamatan seseorang hanya mungkin didapatkan jika orang tersebut menjadi anggota gereja dan mengakui Yesus Kristus sebagai juru selamat. Seorang teolog Kristen Protestan yang dianggap memegang teguh posisi ini adalah Karl Barth dan Hendrik Kraemer (Samosir, 2010).

Menurut Al Qurtuby, jika dibuat semacam tingkatan, maka eksklusivisme menempati tingkatan paling rendah karena sifatnya yang tertutup, antidialog dan konservatif, bahkan cenderung fundamentalis. Pendekatan ini menilai yang lain dari perspektif agamanya sendiri. Agamanyalah yang paling dianggap autentik dan berisi satu-satunya jalan keselamatan dan kebenaran (Qurtuby, 2020). Senada dengan itu, Kleden menyebut eksklusivisme menekankan kebenaran mutlak agama sendiri dan menolak partisipasi semua agama lain dalam kebenaran dan keselamatan (Kleden, 2013). Sikap demikian ibarat menciptakan bom waktu yang akan melahirkan sikap ekstrim dalam beragama, bahkan teror atas nama agama. Pandangan bahwa agamanya sendiri yang paling benar sedangkan agama lain palsu atau salah, hanya akan memunculkan fanatisme buta yang berujung pada sikap antagonistik dan antipati terhadap penganut 
agama lain (Irfanullah \& Hasse, 2016).

\section{Inklusivisme}

Para teolog Katolik yang muncul sebelum Konsili Vatikan II seperti H. de Lubac dan Jean Daniélou dikenal sebagai teolog pembaruan yang memasukkan posisi agama lain ke dalam pemikiran mereka. Teori mereka dikenal dengan teori bahwa Kekristenan menempati posisi puncak, sementara agama-agama lain adalah persiapan menuju wahyu Allah dalam Yesus Kristus. Generasi teolog yang lebih muda dari kelompok ini, misalnya Karl Rahner (Samosir, 2010).

Pandangan inklusif Rahner termuat dalam bukunya The Theological Investigation. Menurutnya, orang-orang yang hidup sebelum karya keselamatan Kristus hadir atau yang belum pernah tersentuh Injil disebut sebagai "Kristen anonim." Mereka akan memperoleh keselamatan juga jika menjalani ketulusan hidup di hadapan Tuhan, sebab karya Tuhan pun ada dalam diri mereka, sekalipun belum mendengar berita Injil (Qurtuby, 2020). Inklusivisme memberi ruang kepada agama lain untuk berpartisipasi dalam kebenaran agama sendiri (Kleden, 2013).

\section{Pluralisme}

Kelompok ketiga disebut sebagai kelompok pluralis yang mempercayai bahwa tentunya setiap agama memiliki jalan keselamatannya sendiri. Oleh karena itu, klaim bahwa Kekristenan adalah satu-satunya jalan, melengkapi jalan lain, adalah sesuatu yang harus ditolak karena alasan teologis dan fenomenologis. Tokoh utama dari kelompok ini ialah John Hick dalam karyanya, God and the Universe of Faiths (Qurtuby, 2020).

Menurut kelompok ini, setiap agama mempunyai rujukan kebenaran sendiri dan karena itu mempunyai hak hidup dan mengembangkan dirinya. Allah yang satu menggemakan suara dan memantulkan wajahNya dalam sekian banyak agama. Tidak ada agama yang dapat menyebut diri sebagai yang lebih benar dari yang lain (Kleden, 2013).

Ketiga sikap teologis tersebut (eksklusivisme, inklusivisme, dan pluralisme) dikembangkan oleh Alan Race, seorang teolog Anglikan. Dirinya kemudian dikenal dalam studi teologi agamaagama sebagai orang yang memopulerkan istilah tipologi tripolar yang digunakannya dalam buku
Race berjudul Christians and Religious Pluralism (Harmakaputera, 2014).

Race sendiri mengakui bahwa tipologi tersebut sebetulnya bukanlah pemikirannya sendiri, melainkan bersumber dari Carl F. Hallencreutz dan Eric J. Sharpe. Namun, nama Alan Race lah yang kemudian dianggap sebagai pencetus tipologi tripolar tersebut. Dengan demikian, terlepas dari banyaknya kritik terhadap penggunaan tipologi tripolar tersebut dan terhadap posisi-posisi di dalamnya, pendekatan tipologi tripolar tetap mempunyai peran besar sebagai pendekatan yang menggerakkan diskursus teologi agama-agama hingga akhir tahun 1990-an (Harmakaputera, 2014).

\section{Dialog Antariman Sebagai Hakikat Keberadaan: Perspektif Kristiani}

Akhir 1960-an dan awal 1970-an di lingkungan Kristiani memang merupakan babak baru dalam memandang relasi dengan umat beragama lain. Hal ini dimulai dengan Konsili Vatikan II (1962-1965) oleh Gereja Katolik Roma yang berisi seruan untuk mengusahakan dialog dengan umat beragama lain. Sementara dari pihak Protestan diadakan Sidang Komite Sentral Dewan Gereja Sedunia (DGD) di Addis Ababa, Etiopia pada tahun 1971, yang mengeluarkan panduan sementara untuk dialog (Banawiratma \& Bagir, 2010). Secara umum, dialog antariman atau agama biasanya mencakup empat level dialog yaitu "dialog kehidupan, dialog kerjasama, dialog kesepahaman pertukaran intelektual, serta dialog pengalaman spiritual" (Irfanullah \& Hasse, 2016).

Lalu, mengapa dialog antariman menjadi amat penting? Menurut Hans Harmakaputera, dialog dalam konteks ini bukanlah sekadar berbicara, melainkan lebih jauh, menelaah relasi dan persekutuan di antara umat beriman yang satu dengan yang lain. Berbicara, aksi bersama, berdoa bersama, adalah bentuk-bentuk dari dialog tersebut, tapi hakikat dari dialog adalah relasi dan persekutuan. Alasan yang sering digunakan untuk mendukung dialog antariman biasanya adalah alasan sosiologis, seperti menciptakan perdamaian, membangun bangsa dan negara, menghindari konflik, demi kemanusiaan yang lebih baik, dan untuk memperjuangkan kelangsungan ekologis. Tentu saja alasan-alasan tersebut tidak salah dan memang diperlukan. Akan tetapi, dialog antariman dari perspektif 
Kristen memiliki alasan yang lebih dalam dan berhubungan dengan hakikat keberadaan (reason for being) umat Kristen (Harmakaputera, 2014).

Gereja sendiri telah mengeluarkan dokumen Redemptoris Missio (RM) yang di dalamnya menyebutkan bahwa "dialog antaragama adalah bagian dari misi Gereja. Selain itu, dialog bukan berasal dari kepedulian-kepedulian taktis atau pun dari kepentingan diri sendiri, melainkan suatu kegiatan yang memiliki prinsip-prinsip penuntunnya, tuntutan-tuntutan, dan kelayakannya sendiri. Dialog dituntut oleh suatu rasa hormat yang mendalam akan segala sesuatu yang telah dihasilkan dalam diri manusia oleh Roh yang bertiup ke mana saja dikehendakinya ((Viktorahadi, 2017).

Menurut Anas Aijudin yang mengutip Sumartana, melalui dialog akan ada kemungkinan masing-masing peserta dialog untuk mengalami perubahan dalam berinteraksi antara satu dengan lainnya, lebih terbuka terhadap mitra dialognya, atau setidaknya lebih memahami keyakinan, pemikiran, dan persoalan yang dihadapi oleh rekan dialognya (Aijudin, 2017). Orientasi dari dialog antariman ini adalah untuk dapat memperkaya pengalaman keberagamaan dari masing-masing pihak, mencari titik temu, serta mengembalikan hakikat agama sebagai instrumen perdamaian dan kasih sayang (Aijudin, 2017).

Berdialog dengan yang lain tidak berarti melepas keyakinan yang dipegang. Bahkan muncul pertanyaan apakah dialog akan merusak identitas Kristiani dari subjek-subjek yang terlibat di dalam dialog tersebut. Perlu diingat bahwa dalam konteks Indonesia yang plural baik dalam hal agama maupun budaya, identitas Kristiani semestinya dipahami dalam kerangka relasional, bukan pembedaan atau isolasional (Viktorahadi, 2017). Seorang pribadi ataupun komunitas dalam konteks ini tidak dimaknai dalam keberbedaannya dengan yang lain, tetapi terkait bagaimana relasinya dengan yang lain (Viktorahadi, 2017).

Penekanan identitas Kristiani dengan jalan mengisolasi diri dari perjumpaan dengan yang lain sesungguhnya bertolak belakang dengan hakikat identitas Kristiani itu sendiri. Dalam konteks ini identitas harus bersifat overlapping. Keterasingan komunitas Kristiani tak bisa diselesaikan hanya dengan sloganisme. Menurut Viktorahadi, keterasingan dengan subyek lain harus di atasi dengan jalan membangun jembatan relasional, khususnya melalui aksi-aksi pembebasan bersama bagi saudara-saudara beriman lain yang mengalami peminggiran dan diskriminasi (Viktorahadi, 2017).

Lebih lanjut, Viktorahadi menyebut bahwa studi yang benar terhadap satu tradisi keyakinan sendiri maupun keyakinan iman lain sejatinya akan sampai pada kesimpulan bermanfaat jika dimotivasi oleh penghargaan yang mendalam terhadap kekhasan setiap tradisi keyakinan. Hal ini harus dibarengi dengan sikap tanpa pretensi untuk merendahkan atau mengagungagungkannya (Viktorahadi, 2017). Jika seseorang dari tradisi keyakinan yang berbeda tidak dapat menumbuhkan kasih terhadap penganut keyakinan yang berbeda, yang pada hakikatnya adalah sesama manusia ciptaan Tuhan, sebuah studi atau usaha berdialog antariman yang selama ini diusahakan hanya akan menjadi sebuah tumpukan informasi tanpa daya transformatif (Viktorahadi, 2017).

Umat Kristen memercayai Allah yang mengejawantahkan diri-Nya di dalam tiga pribadi, yakni Bapa, Anak, dan Roh Kudus (Allah Trinitas), yang dimungkinkan oleh gerak perikoresis dari ketiganya. Gerak perikoresis adalah gerak saling memberi diri Allah di dalam diri-Nya sendiri sehingga kemudian menghasilkan kehidupan. John D. Zizioulas sebagaimana dikutip Harmakaputera mengatakan bahwa hakikat (being) Trinitas adalah persekutuan (Harmakaputera, 2014).

Karena itu, hakikat manusia tidak pernah "ada" begitu saja, melainkan harus "ada-didalam-relasi-dengan." Dengan demikian, relasi dan persekutuan adalah hakikat dari umat Kristiani sebagaimana hakikat Allah Tritunggal adalah relasi dan persekutuan. Konsekuensinya, umat Kristiani wajib menjalin relasi dan persekutuan bukan hanya dengan Allah dan sesama umat Allah, melainkan dengan seluruh manusia tanpa kecuali (Harmakaputera, 2014).

\section{Persahabatan: Belajar dari Sejarah Relasi Islam- Kristen-Yahudi}

Pendekatan pragmatis dalam perjumpaan dengan orang-orang dari agama yang berbeda, membentuk rasa toleransi Islam sepanjang perjumpaannya dengan agama Kristen, Yudaisme, dan agama lain selama Abad Pertengahan. Al-Ghazali, seorang sufi, 
berpendapat, bahwa cinta kepada Tuhan itu hanya dimungkinkan ketika manusia menjalin persahabatan dengan yang lain. Hal ini didasarkan pada keyakinan yang kuat bahwa Tuhan mencintai makhluk ciptaannya, dan cinta itu dapat mengarah pada persahabatan yang transformatif, baik dengan Tuhan maupun dengan sesama manusia. Timbal balik dalam persahabatan dipandang sebagai anugerah dari Tuhan "yang merupakan sumber segalanya" (Aihiokhai, 2019).

Sejarah hubungan kaum Muslim dengan orang-orang dari agama lain berbicara kepada gerakan perdamaian positif yang muncul dari kepercayaan dan rasa hormat terhadap kepercayaan-kepercayaan dari agama lain. Persahabatan antara Nabi Muhammad dan Negus (Raja) Ethiopia adalah contoh bagaimana gerakan perdamaian positif yang muncul dari rasa hormat dan percaya. Sebagaimana dikatakan oleh Clinton Bennett, Nabi Muhammad mengirim pengikut Muslimnya yang melarikan diri karena penganiayaan dari Mekah ke Ethiopia. Orang Kristen penguasa Ethiopia bersedia memberikan perlindungan kepada kaum muslimin yang ia dianggap sebagai saudara dan saudari. Menanggapi keramahan yang ditunjukkan oleh penguasa Kristen Ethiopia, Nabi Muhammad menginstruksikan para pengikutnya untuk menghormati netralitas Ethiopia selama penaklukan oleh Islam (Bennett, 2008).

Perjanjian antara Nabi Muhammad dan komunitas Yahudi Madinah membenarkan dasar toleransi beragama selama permulaan awal Islam. Dalam perjanjian ini, nabi mengakui hak komunitas Yahudi untuk mengamalkan iman mereka tanpa dorongan dan harapan agar komunitas tersebut menjadi pemeluk agama Islam (Bennett, 2008).

Pendekatan pragmatis nabi tersebut memengaruhi banyak penerusnya dalam memandang agama lain sebagai mitra penting dalam masyarakat. Bahkan praktik perpajakan kepada non-muslim yang tinggal di wilayah Muslim tidak boleh dilihat sebagai sarana untuk menundukkan agama lain; lebih tepatnya, ini adalah cara pragmatis untuk mengatasi ketegangan yang terkait dengan pluralisme agama dalam masyarakat yang majemuk secara sosial dan budaya.

Bagi banyak penguasa Muslim, termasuk penguasa Ottoman, pembayaran pajak semacam itu ditunjukkan sebagai tanda penyerahan diri dan ketundukan kepada Tuhan oleh para pembayar pajak. Sebagai imbalannya, para penguasa Muslim mengakui hak-hak warga non-Muslim untuk menjalankan keyakinan mereka dengan tidak terganggu (Bennett, 2008). Kekristenan dan Yudaisme berkembang di banyak wilayah Muslim karena pendekatan pragmatis ini.

\section{Persahabatan Antariman yang Autentik dari Perspektif Kristiani}

Konsep persahabatan bukanlah sesuatu yang baru dan bukan khas ajaran agama tertentu termasuk Kristen. Istilah "sahabat" bahkan ditulis secara panjang lebar oleh filsuf Aristoteles dalam buku Nicomachean Ethics-nya yang terkenal (Fredericks, 1998). Akan tetapi menurut penulis, adalah penting untuk melihat persahabatan dari konteks Kristiani dan bagaimana praksisnya dalam konteks relasi antariman.

Dialog yang benar-benar autentik hanya mungkin terjadi jika terbangun dalam relasi yang menubuh (embody) melalui persahabatan antariman. Oleh karena itu tak mengherankan jika dari pihak Kristen, The World Council of Churches (WCC) atau yang dikenal sebagai dewan gereja dunia mengeluarkan dokumen Christian SelfUnderstanding. Dokumen tersebut berisi respons atas perjumpaan umat Kristen dengan umat beragama lain. Dalam dokumen tersebut ditegaskan bahwa berelasi antariman merupakan bagian yang tidak dapat dipisahkan dari kehidupan umat Kristen (Probo, 2015).

Dewan gereja tersebut juga merekomendasikan supaya dokumen Christian Self Understanding disebarluaskan kepada orang Kristen lainnya untuk mendorong agar mereka mengenal, memahami, dan menawarkan persahabatan yang tulus kepada pemeluk agama lain. Hal tersebut dianggap penting untuk mengurangi sikap menghakimi maupun sikap memandang ajaran agamanya sendiri lebih baik daripada ajaran umat beragama lainnya (Probo, 2015).

Apa dasar teologis persahabatan antariman dalam perspektif Kristen? Pertama, Abraham, tokoh sentral dalam agama Samawi digambarkan dalam Alkitab sebagai sahabat Allah (Yakobus $2: 23)$. Hal tersebut berarti bahwa dalam persahabatan tidak menuntut kualitas pribadi 
yang seimbang atau setara. Persahabatan terjalin dari dua pribadi yang berbeda dalam hal pengetahuan, kekuatan, dan kebajikan (Volf \& McAnnally-Linz, 2015).

Dalam Alkitab Perjanjian Lama, konsep sahabat banyak ditemukan dalam Kitab Amsal. Kata sahabat dalam konteks tersebut juga dapat diartikan sebagai tetangga. Hal ini sekaligus berarti bahwa sahabat adalah mereka yang dekat, baik secara fisik maupun dalam hal relasi. Intensitas perjumpaan menjadi benih-benih munculnya persahabatan. Sahabat adalah mereka yang dekat dalam berbagai situasi kehidupan (Susanta, 2018).

Kedua, dalam Kitab-kitab Injil, Yesus seringkali disebut sebagai sahabat pemungut cukai dan orang berdosa (Mat 11:19; Lukas 7:24). Bahkan, Yesus banyak menghabiskan waktu bersama mereka dan mereka pun seringkali mencari Dia (misalnya dalam Markus 2:16; Lukas 15: 1-2, dan lain-lain). Dengan demikian, persahabatan tak menutup kemungkinan dapat terjalin di antara mereka yang berbeda kebajikan, dan yang hidupnya sebenarnya tidak berorientasi pada tujuan yang sama (Volf \& McAnnally-Linz, 2015).

Ketiga, Yesus secara eksplisit berkata bahwa kasih paling besar adalah kasih seorang sahabat yang memberikan nyawanya untuk sahabatsahabatnya (Yoh. 15:13) (Volf \& McAnnally-Linz, 2015). Hal senada dengan ini sesungguhnya juga ditemukan dalam ajaran Islam sebagaimana dikatakan oleh Gianotti bahwa Nabi Muhammad mengatakan bahwa salah satu jalan masuk ke Surga adalah dengan mengasihi sahabat,

Many strong traditions attest to this linking of faith and friendship, both in this world and the next. For example, the Prophet is also reported to have said, "You shall not enter Paradise until you believe; and you shall not believe until you love one another" (Gianotti, 2015).

Selanjutnya, James L. Fredericks dalam artikelnya yang berjudul Interreligious Friendship: A New Theology Virtue, dengan gamblang dan tegas mengatakan bahwa persahabatan antariman adalah bentuk dari kebajikan. Fredericks mengurai konsep tersebut ke dalam empat tahapan (Fredericks, 1998).

Pertama, kebajikan secara umum merupakan gabungan dari keterampilan seseorang, nilai sejarah yang ada di dalamnya, dan koreksi atas sifat yang buruk atau perbuatan yang jahat. Kedua, bentuk dari persahabatan yang sejati adalah persahabatan kepada orang asing atau befriending the stranger. Persahabatan dengan yang lain atau orang asing tersebut melahirkan nilai desentralisasi ego diri dan memperluas wawasan kita yang seakan "dibatasi" kepada yang lain (the others). Ketiga, nilai-nilai kebaikan dan kebenaran yang ditemukan dalam agama lain dapat menciptakan dan mentransformasi kualitas iman serta kebenaran yang ada dalam diri kita menjadi lebih baik. Persahabatan antariman mendatangkan manfaat besar guna memperbaiki kekurangan dan inkonsistensi pengamalan iman kita sendiri. Persahabatan antariman berpotensi untuk mengkonstruksi ataupun merekonstruksi kehidupan seluruh manusia secara umum dan diri kita sendiri secara khusus menjadi lebih baik (Fredericks, 1998).

Dalam konteks Kristen, terdapat beberapa perintah yang mendorong untuk berbuat baik kepada sesama. Misalnya teks Lukas 6:33 dalam versi bahasa sehari-hari dikatakan "Jika kamu hanya berbuat baik kepada orang yang berbuat baik kepadamu, pantaskah kamu mendapat pujian?" Perbuatan baik dalam konteks ini berlaku untuk semua orang, walaupun berbeda termasuk dalam hal keyakinan. Dalam Alkitab khususnya Perjanjian Baru ditekankan bagaimana menerima orang dari segala bangsa karena universalitas dari kasih Allah. Dalam konteks persahabatan, perbuatan baik bukan sekadar kewajiban melainkan bagian dari identitas Kristiani. Perbuatan baik yang dilakukan terhadap sahabat akan kembali kepada diri sendiri. "Segala sesuatu yang kamu kehendaki supaya orang perbuat kepadamu, perbuatlah demikian juga kepada mereka" (Mat. 7:12).

\section{Kesimpulan}

Pola relasi antariman dalam konteks Indonesia yang umumnya dijumpai adalah tipologi tripolar yaitu eksklusivisme, inklusivisme, dan pluralisme. Sejumlah kritik telah hadir terhadap model tipologi tripolar tersebut serta sekaligus berupaya melampauinya. Tulisan ini memperlihatkan salah satu alternatif dalam relasi antariman yaitu persahabatan antariman. Dialog yang sejati atau autentik dapat terjadi dalam persahabatan antariman. Dialog yang terjalin dalam konteks tersebut berupaya untuk 
meruntuhkan tembok pemisah atau sekat klaim kebenaran absolut yang dianut sebagian umat beragama. Dialog persahabatan juga menawarkan seperangkat penghayatan iman yang melintas dan menyelami agama-agama lain tanpa harus kuatir kehilangan identitas keyakinan sendiri. Umat Kristiani wajib menjalin relasi dan persekutuan bukan hanya dengan Allah dan sesama umat (orang Kristen), melainkan dengan seluruh manusia tanpa terkecuali. Identitas Kristiani seharusnya dimaknai dalam kerangka relasional dengan yang lain. Dialog persahabatan pada gilirannya akan memperkaya setiap pelaku dialog dengan jalan menggali kekayaan tradisi agama lain sekaligus menyegarkan apa yang diimaninya.
Nilai-nilai kebaikan dan kebenaran yang terkandung dalam ajaran agama lain dapat menciptakan dan mentransformasi kualitas iman serta kebenaran yang ada dalam diri sendiri menjadi lebih baik.

\section{UCAPAn Terima KasiH}

Penulis mengucapkan terimakasih kepada Febriani Upa' mahasiswa pascasarjana Institut Agama Kristen Negeri Toraja yang telah membantu memberikan masukan dalam penyelesaian tulisan ini. 
Aihiokhai, S. A. A. (2019). Fostering Interreligious Encounters in Pluralist Societies. Cham: Springer International Publishing. https:// doi.org/10.1007/978-3-030-17805-5

Aijudin, A. (2017). Mengelola Pluralisme Melalui Dialog Antar Agama (Sebuah Tinjauan Teoritik). Jurnal SMaRT: Studi Masyarakat, Religi Dan Tradisi, 3(1), 119-124. https:// doi.org/10.18784/smart.v3i1.493.g294

Appleby, R. S. (2000). The Ambivalence of the Sacred: Religion, Violence, and Reconciliation. Lanham, Boulder, New York, and Oxford: Rowman \& Littlefield Publishers.

Banawiratma, J. B., \& Bagir, Z. A. (2010). Dialog Antarumat Beragama. Jakarta: Mizan.

Bennett, C. (2008). Understanding Christian-Muslim Relations: Past and Present. London: Continuum.

Fredericks, J. L. (1998). Interreligious Friendship: A New Theology Virtue. Journal of Ecumenical Studies, 35(2), 159-174.

Gianotti, T. J. (2015). Toward a Muslim Theology of Interreligious Friendship. In A. GoshenGottstein (Ed.), Friendship across Religion: Theological Perspective on Interreligious Friendship (pp. 77-95). Lanham, Boulder, New York, and London: Lexington Books.

Harmakaputera, H. A. (2014). Melepas Bingkai: Upaya Pencarian Jalan-jalan Lain yang Mengatasi Kebuntuan Model Pendekatan Tipologi Tripolar dalam Diskursus Teologi Agama-agama Kontemporer. Jakarta: Grafika Kreasindo.

Irfanullah, G., \& Hasse, J. (2016). Dialog Sufistik: Membangun Relasi antar-Agama yang Konstruktif. Ilmu Ushuluddin, 3(1), 69-80. https://doi.org/10.15408/jiu.v3i1.4852

Kleden, P. B. (2013). Membongkar Berhala, Membangun Sikap BerAllah: Spiritualitas Terlibat dalam Konteks Pluralitas Agama. In Agama-agama dan Dialog Antar-Agama dalam Pandangan Kristen (pp. ix-xxx).

Küng, H. (2010). Kapasitas untuk Berdialog dan
Keteguhan Iman Tidak Bertentangan. In Jalan Dialog Hans Küng dan Perspektif Muslim. Yogyakarta: CRCS UGM.

Magnis-Suseno, F. (2014). Iman dan Hati Nurani: Gereja Berhadapan dengan Tantangantantangan Zaman. Jakarta: Penerbit Obor.

Mulia, M. (2013). Melawan Kekerasan atas Nama Agama. In J. Campbell-Nelson, J. Mojau, \& Z. J. Ngelow (Eds.), Teologi Politik: Panggilan Gereja di Bidang Politik Pascaorde Baru (pp. 165-194). Makassar: Oase INTIM.

Nazmudin. (2017). Kerukunan dan Toleransi Antar Umat Beragama dalam Membangun Keutuhan Negara Kesatuan Republik Indonesia (NKRI). Journal of Goverment and Civil Society, 1(1), 23-39.

Nur Hidayati, M. T. H. D. (2019). PERAN KOMISI HUBUNGAN ANTAR UMAT BERAGAMA GEREJA KATOLIK DALAM MEMBANGUN DIALOG. RELIGI JURNAL STUDI AGAMA-AGAMA, 14(2), 194. https:/ /doi.org/10.14421/rejusta.2018.1402-03

Osborne, K. B. (2015). The Infinity of God dan a Finite World: A Fransiscan Approach. New York: St Bonaventure University.

Panda, H. P. (2013). Agama-agama dan Dialog AntarAgama dalam Pandangan Kristen. Maumere: Ledalero.

Probo, B. (2015). Ketua STT Jakarta: Penginjilan Bukan Proyek Kristenisasi. Retrieved January 2, 2021, from Satu harapan website: http://www.satuharapan.com/read-detail/ $\mathrm{read} /$ ketua-stt-jakarta-penginjilan-bukanproyek-kristenisasi

Qurtuby, S. Al. (2020). Dekonstruksi Teks dan Transformasi Agama: Tribute Untuk John A. Titaley. Yogyakarta: Elsa Press.

Ronda, D. (2019). PERAN KEPEMIMPINAN KRISTEN MEMBANGUN DIALOG ANTAR UMAT UMAT BERAGAMA. Voice of Wesley: Jurnal Ilmiah Musik Dan Agama, 2(2), 1-7. https://doi.org/10.36972/ jvow.v2i2.25 
Samosir, L. (2010). Agama dengan Dua Wajah: Refleksi Teologis Atas Tradisi dalam Konteks. Jakarta: Penerbit Obor.

Sumartana, T. (2005). Mata Rantai dan Strukturstruktur Kekerasan di Indonesia. In E. Sitompul (Ed.), Agama-agama: Kekerasan dan Perdamaian (pp. 52-62). Jakarta: Bidang Marturia PGI.

Susanta, Y. K. (2018). “Menjadi Sesama Manusia” Persahabatan sebagai Tema Teologis dan Implikasinya Bagi Kehidupan Bergereja. DUNAMIS: Jurnal Teologi Dan Pendidikan Kristiani. https://doi.org/10.30648/
Viktorahadi, R. F. bhanu. (2017). Aroma Toleransi dalam Sumpah Abraham Demi El Elyon. Wacana Biblika, 17(2), 51-59.

Volf, M., \& McAnnally-Linz, R. (2015). A Christian Perspective on Interreligious Friendship. In A. Goshen-Gottstein (Ed.), Friendship across Religion: Theological Perspective on Interreligious Friendship (pp. 45-67). Lanham, Boulder, New York, and London: Lexington Books. 